\title{
Ethiopia Justice Sectors: Are They Serving Justice or The Politics?
}

\author{
Solomon Dessalegn Dibaba*
}

\begin{abstract}
The criminal justice process involves interrogation of the arrested or accused persons by investigative police; investigation by the public prosecutor which institutes charges; and enforcement of committal for trial by the judiciary. As investigative police and public prosecutor enforce the law, their success or failure is not measured by the number of convictions or case attritions, but by the level of their professionalism and integrity in the course of fair, competent, responsible, effective and efficient performance in accordance with the law. Based on this the paper explores and discusses the rights of arrested or accused persons vis-à-vis the role and responsibility of Ethiopia justice sectors. The paper devoted to assess whether the justice sectors in Ethiopia are serving the justice or politics particularly under the governing body. To address these issues descriptive qualitative research design was used to analyze the gathered data. Primary and secondary sources of data were used. Interview with purposively selected professionals from justice sectors including arrested politicians with their advocators was one of the tools for data gathering and analysis. In addition, documents, news, and features from private and government legal websites were used as secondary sources of data. Further to get necessary information from aforementioned sources of data, writer own observation and document analysis were employed as data gathering tools. Using the mentioned data above, this paper has disclosed the existing problems and substantial recommendations to relieve the existing problems.
\end{abstract}

Keywords: Attorney General, Police Investigation, Judiciary, Role of Government, Justice, Politics and Ethiopia. DOI: $10.7176 / \mathrm{JLPG} / 114-01$

Publication date:October $31^{\text {st }} 2021$

\section{Introduction}

Commencement of criminal justice system begins from information of the commission of crime and ends at execution of court judgment. The information of the commission of the crime could reach the police through different channels. These are complaint, accusation and the occurrence of flagrant offences. The criminal justice process involves interrogation of accused persons by the police; investigation by the public prosecutor which institutes charges; and enforcement of committal for trial or enforcement of sentences by prison administrations. As these three organs enforce the law, their success or failure is not measured by the number of convictions or case attritions, but by the level of their professionalism and integrity in the course of fair, competent, responsible, effective and efficient performance in accordance with the law. From information of the commission of the crime up to punishment of the criminal's: police, public prosecutor, courts of law and prison administrations are the organs involved in the criminal justice process. Once the criminal justice triggered, it is often followed by investigation to substantiate the case with evidence to prove guilt.

A criminal justice system may have a spectrum of features ranging from primacy to due-process vis-à-vis focus on crime control model. Criminal justice systems tend not to fall completely within one model or the other: most seek to strike a balance between the two. ${ }^{1}$ The due-process model gives priority to fairness of procedure and to protecting the innocent from wrongful conviction, accepting that a high level of protection for suspects makes it more difficult to convict the guilty and that some guilty people will therefore go free. ${ }^{2}$ Crime control model places most importance on convicting the guilty, taking the risk that occasionally some innocent people will be convicted. ${ }^{3}$ The Ethiopian criminal justice system seems to reflect the due process model.

This paper focuses on and explores the following important points: first, it mainly discusses rights of suspected, arrested and accused persons incorporated in Ethiopia substantive and procedural law. Second, it discusses the role and responsibility of Ethiopia justice sectors vis-à-vis the rights of suspected, arrested and accused persons. Finally, this paper assess whether the justice sectors in Ethiopia are serving the justice or politics under the transitional government led by Prime Minister Abiy Ahmed. To address these points provided above the writer used primary and secondary source of data for strong based evidence. Purposive sampling was employed to select the sources of data and tools of data gathering and analyzing. The primary sources were totally twenty-five (25) key informants. Accordingly, eight (8) advocators from Oromia political prisoners

\footnotetext{
* The author has got LLB (Mekelle University, School of Law), LLM in Environment and Land Law (Hawassa University, School of Law), currently, Lecturer at Law in Oromia State University, Finfinne, Ethiopia, and Coordinator of LLM programme given by Vrije University of Amsterdam in collaboration with Oromia State University. Possible to reach the author through: e-mail: solomondesalegn6@gmail.com

${ }^{1}$ Catherine Elliot and France Quinn, English legal system, (England: person education limited, $6^{\text {th }}$ ed., 2005), p 338

2 James A. Inciardi, Criminal justice, (Fort Worth: Harcourt, Inc., Alabama ed., $7^{\text {th }}$ ed., 2002), p 13

${ }^{3}$ Id
} 
defense team, five (5) arrested persons released on bail, three (3) judges from federal first instance and high court, four (4) judges from Oromia first instance and high court, two (2) investigative police officers from federal police, and two (2) investigative police officers from Oromia police. In addition, documents, news, and features from private and government legal websites were used as secondary sources of data. Further to get necessary information from aforementioned sources of data, writer own observation and document analysis were employed as data gathering tools. The descriptive qualitative research design was used to analyze the gathered data.

\section{Ethiopian criminal justice system}

When we say system, we really mean it! Law enforcement efforts feed into the court system. The court system feeds into the correctional system. ${ }^{1}$ Each and every decision made at each and every stage has consequence for latter stages. The more people arrested the more defendants in court. The more defendants in court the more inmates in prison. An influential group of criminal justice thinkers has argued that just as a society must maintain armed force to defend itself against foreign aggressors; it must maintain a force of internal peacekeepers to defend itself against aggression from within. Social defense demands a criminal justice system, whose purpose, goal, or end is to defend society. ${ }^{2}$ The end of criminal justice is criminal justice. The criminal justice system can do no more than deliver criminal justice. The end product must be justice (done justice, perceived justice, etc.), and at each stage of the process justice must also be applied and delivered.

Herbert Packer, in the limits of criminal sanction, ${ }^{3}$ has made an important contribution to identifying the methods by which criminal justice seeks to achieve its goals. He presents two approaches for the criminal justice process: the due process model and the crime control model. The due process model requires strict adherence to the constitution. The focus is squarely on the accused and on his or her rights. It limits the power and authority of investigative police officer. Quite simply, due process protections under the constitution force the state to fulfill its burden of proving its case against the accused. Packer describes the due process model as an obstacle course: each stage creates barriers to the successful prosecution of an accused. The crime control model focuses on the efficiency and effectiveness of the process. The criminal process exists to investigate crimes, screen suspects, detain dangerous defendants, and secure convictions of guilty parties. This should be done with speed and finality. Each agency at every stage the process assumes the responsibility for dealing efficiently with the criminal case. The crime control model resembles an assembly line: efficiency, productivity, and reliability are its hallmarks. Constitutional rights take second place to the desirability of the processing offenders quickly and successfully.

Referring the grand constitution and other subordinate laws Ethiopia criminal justice process resembles to the due process model. The constitution provides that arrested persons shall not be compelled to make confession or admission which could be used in evidence against them. ${ }^{4}$ Any evidence obtained under coercion shall not be admissible. It also provides that arrested persons have the right to remain silent. ${ }^{5} \mathrm{Up}$ on arrest, they have the right to be informed promptly, in a language they understand, that any statement they make may be used as evidence against them in court. Besides, no police officer or person in authority shall offer or use or make or cause to be offered, made or used any inducement, threat, promise or any other improper method to any person examined by the police. ${ }^{6}$ Further persons arrested have the right to be brought before a court within 48 hours of their arrest. ${ }^{7}$ On appearing before a court, they have the right to be given prompt and specific explanation of the reasons for their arrest due to the alleged crime committed. ${ }^{8}$ The other important point that explicitly indicates Ethiopia criminal justice process resembling to due process model is the right of accused persons that during proceedings have the right to be presumed innocent until proved guilty according to the law and not to be compelled to testify against themselves. ${ }^{9}$ Also accused persons have the right to full access to any evidence presented against theme, to examine witnesses testifying against them, to adduce or to have evidence produced in their own defense, and to obtain the attendance of and examination of witnesses on their behalf before the court. ${ }^{10}$

\footnotetext{
${ }^{1}$ Freda Adler, et.al., Criminal justice, p 104

${ }^{2}$ Marc Ancel, Social defense (Thorsten Sellin, transl.), (Little-ton, Colo.: Fred B. Rothman \& Co., 1987)

${ }^{3}$ Herbert Packer, The limits of the criminal sanctions (Stanford, Calif.: Stanford University Press, 1968).

${ }^{4}$ Article 19 (5) of federal democratic republic of Ethiopia (FDRE) constitution of proclamation No. 1/1995, Also see Article 27 (2) of Ethiopia criminal procedure code of proclamation No. 185/1961.

${ }^{5}$ Article 19 (2) of the FDRE Constitution, Also see Article 27 (2) of Ethiopia criminal procedure code.

${ }^{6}$ Article 31 (1) of Ethiopia criminal procedure code (1961)

${ }^{7}$ Article 19 (3) of the FDRE Constitution Proclamation No 1/1995, Also see Article 29 (1) of Ethiopia criminal procedure code of Proclamation No. 185/1961.

${ }^{8}$ Id

${ }^{9}$ Article 20 (3) of the FDRE Constitution Proclamation No. 1/1995

${ }^{10}$ Article 20 (4) of the FDRE Constitution Proclamation No. 1/1995
} 


\section{Ethiopia Justice Sectors v. Justice}

This subtitle discusses the rights of suspect, arrested or accused persons under substantive and procedural laws in case of Ethiopia briefly, details the roles of justice sectors in relation to rights of suspected, arrested or accused persons under Ethiopia criminal justice system, and finally it discusses the findings as to the issues of whether the Ethiopia justice sectors serving justice or the politics. Until the $1960 \mathrm{~s}$, criminal justice procedures from arrest to conviction were generally not seen as orderly process like that of manufacturer's production line. ${ }^{1}$ But from 1967 the criminal justice system passes through an orderly process that comprises five interrelated phases with four paths. ${ }^{2}$ One of the phase, called entry into the system by which citizens play an important role by bringing criminal events to the attention of the police. The police investigate the case and identify a suspect. The judiciary issues search and arrest warrants. The second phase, prosecution and pretrial services, dominated by prosecutors, who prepare the charges; who indict defendants; and judges, who conduct a series of hearings, including the initial appearance of an arrested person at court and a preliminary hearing. The third phase, adjudication, begins with an arraignment, at which the officially accused person pleads to answers the formal charges (indictment or information) against him or her, and ends with a judgment of guilty or not guilty. This phase is conducted by a judge. The prosecutor, representing the state and people, and the defense lawyer play the most active roles.

After arrest, when the suspect is in custody, the arresting police officer must recite the Miranda warning explaining the rights of an arrestee. The Miranda warning derives from one of the America Supreme Court's most important rulings, which laid down the standards of procedural fairness mandated by the fourth, fifth, and six amendments to the constitution. ${ }^{3}$ If the warning is not given, a judge may exclude from evidence presented at trial any incriminating statement the arrestee may have made, as well as any evidence that resulted from it. ${ }^{4}$ As discussed above the same right recognized and incorporated in Ethiopia constitution and other subordinate laws. Persons summoned or arrested by investigative police officer have the right to remain silent. ${ }^{5}$ Up on arrest, they have the right to be informed promptly, in a language they understand, that any statement they make may be used as evidence against them in court. ${ }^{6}$

When we see the practice in Ethiopia particularly in the study area, Miranda warning not implemented effectively. An interview made with investigative police officers from both the federal and Oromia and with arrested persons released on bail indicates as Miranda warning not implemented most of the time. ${ }^{7}$ As they said it is because of most of the time crime investigation undertaken not scientifically but traditionally that doesn't require professionalism, and the other is because of ignorance of the law by the police itself. ${ }^{8}$ On the other side responses of investigative police officer indicates even majority of persons arrested were ignorant of their rights incorporated in the constitution and procedural laws. ${ }^{9}$ Most of the time arrest by police effected without observing and ensuring the procedures incorporated in Ethiopia criminal procedure. ${ }^{10}$ That means most of the time arrest by police made without arrest warrant or without determining whether the crime committed justify arrest or not. ${ }^{11}$ As incorporated in the constitution and criminal procedure persons arrested have the right to be brought before court within 48 hours. And where investigative police officer failed to bring arrested persons before courts of law within $48 \mathrm{hrs}$ they have inalienable rights to petition courts of law for their physical release. $^{12}$ The practice clearly shows as arrested persons weren't brought before courts of law within 48 hrs. Most of the time arrested persons who asked courts of law for their physical release were not granted such rights without just reasons recognized by law. Especially after the death of iconic Oromo figures Hachalu Hundesa thousands were imprisoned throughout the Oromia region. Results of observation in five towns of Oromia region (Batu, Shashamanne, Burayu, Ambo, and Sebeta) indicates that thousands of Oromo youngsters were thrown to detention centers without knowing reasons for their arrest and majority of them for months were not brought before courts of law. Following shot to death of iconic Oromo figure Hachalu Hundesa Oromo opposition political party from both Oromo Liberation Front (OLF) and Oromo Federalist Congress (OFC) were arrested by

\footnotetext{
${ }^{1} \operatorname{Id~n}(4), \mathrm{p} 107$

${ }^{2}$ President's Commission on Law Enforcement and the Administration of justice, The Challenge of Crime in a Free Society (Washington, D.C.: U.S. Government printing office, 1967).

${ }^{3}$ Miranda v. Arizona, 384 U.S. 436 (1996), Miranda warnings are not always recited at the time of arrest and may, depending on the jurisdiction, be recited when the suspect is booked or prior to any custodial interrogation.

${ }^{4}$ But there is an exception to this rule: When public safety is at risk, the warning may be postponed, See New York v. Quarles, 467 U.S. 649 (1984).

${ }^{5} \operatorname{Id~n}(8)$

${ }^{6} \mathrm{Id}$

${ }^{7}$ An interview conducted with Hailemeskel Berhanu, et al., investigative federal police officer at Lideta Sub-City, and other interview made with Bayissa Gelgelo, et al., investigative Oromia police officer at Burayu town, September 15, 2020

${ }^{8}$ Id

${ }^{9} \mathrm{Id}$

${ }^{10}$ Interview conducted with Hassen Baalli who was arrested because of his political stand against the governing body, and released on bail after three months of arrest in Burayu Police custody, September 25, 2020

${ }^{11}$ Article 26 of Ethiopia criminal procedure proclamation No. 185/1961

${ }^{12}$ Article 19 (4) of the FDRE Constitution Proclamation No. 1/1995
} 
government police without informed reasons of their arrest and they were not charged before courts of law within $48 \mathrm{hrs}$. Some of them their where about is unknown for more than five months.

Tola Bayu one of the interviewee arrested in Sebeta police custody told me as he was in custody for three months without informed the reason of his arrest by the law enforcer and he was not charged before courts of law. Tola Bayu tried to reach his case for release before courts of law but failed because he has no one that bring his case before courts of law. His family and friends is far from Sebeta and they didn't know his where about. He was arrested from Finfinnee (Addis Ababa) the capital city but taken to Sebeta police custody which found in Oromia region. ${ }^{1}$ The result of interview made with investigative police officer in Sebeta police office discloses that we were forced by the regional and federal government to implement their orders only. ${ }^{2}$ They said we didn't know what their crime is but only enforcing higher federal and regional official's orders. They were ordered not to take the arrested persons before courts of law except when they are permitted to do so. Because of this including Tola Bayu about hundreds arrested persons in Sebeta police custody were not charged before courts of law.

The result of interview from both arrested persons and investigative police officers on one side, and the result of observation from the other side indicate that after the shot to death of iconic public figure of Oromo Hachalu Hundesa the government led by Abiy Ahmed to stay for long in power continued massively arresting opposition political party leaders and their supporters especially the young group in Oromia region. They are arrested mainly because of their political ideology or suspected of being supporters of Oromo opposition political party like Oromo Liberation Front (OLF) and Oromo Federalist Congress (OFC). The government lawless measure is against person's origin, person's rights to hold his or her choice of political belief or person's rights to be a member of his/her own will in political organization. ${ }^{3}$

In Batu town which found in east Shewa of Oromia region following shot to death of music star Hachalu Hundesa about more than five hundred Oromos were arrested without charged before courts of law. Following the killing of music Oromo star Hachalu Hundesa there was peaceful and violent protest throughout Oromia region. For instance, in Batu there was peaceful protest on one side and violent protest that causes destruction of property and loss of life on the other side. And the arrest was following the violent protest that cause destruction of property and loss of life. The problem is almost all arrested persons didn't know why they were in custody and not charged before courts of law for about more than two months. Also the police didn't know the reasons for their arrest but they are enforcing the higher official orders. ${ }^{4}$ After two months of arrest some of them were brought before courts of law and charged with participation in violent acts that causes destruction of properties in Batu town. After repeated remand granted for further investigation by investigative police officer ${ }^{5}$ Batu first instance court ordered the release of almost all detainees. But police failed to enforce orders of court to release the arrested persons alleging that we are ordered by higher political officials to keep them in custody. ${ }^{6}$ From this it is clear that the law enforcement is violating its obligations of enforcing any courts orders or judgments. Because judicial powers ${ }^{7}$ in Ethiopia, both at federal and state levels, are vested in the courts. ${ }^{8}$ Two judges from Batu first instance court were humiliated and thrown to police custody by deployed defense force because they ordered release of the above mentioned arrested persons. ${ }^{9}$ This day in Ethiopia institutional and personal independence of the judiciary ${ }^{10}$ is explicitly eroded and falls in the hands of the dictator government led by Abiy Ahmed. Abiy Ahmed government in collaboration with Amharan's bureaucratic made the justice sectors their instruments to serve only their will that helps them to stay long in power. That is arresting and criminalizing through false accusation those public figures from opposition parties to easily win the coming national election. It is clear once they are criminalized through false accusation they are going to prison to serve the false punishment than participating in the national election. This easily paves way for Abiy Ahmed prosperity party to win the national election for the next five years.

\footnotetext{
${ }^{1}$ An interview made with Tola Bayu who was arrested from Finfinne and taken to Sebeta police custody without being informed reason of his arrest and charged before courts of law for three months, August 25, 2020

${ }^{2}$ An interview made with Takele Bedaso an investigative police officer in Sebeta town police office, August 26, 2020

${ }^{3}$ See Article 25, 38 (2) of the FDRE Constitution Proclamation No. 1/1995, Also see Articles 7, 20 (2), \& 21 (1) of the Universal Declaration of Human Rights (UDHR), Articles 1 (1), 3, 25 (a), \& 26 of the International Covenant on Civil and Political rights (ICCPR).

${ }^{4}$ An interview made with Gurmu Lenjiso and Birhanu Golole, an investigative police officer in Batu police office, September 2, 2020

${ }^{5}$ As per Article $59(2 \& 3)$ of Ethiopia criminal procedure code, where the investigation is not completed the investigating police officer may apply for a remand for a sufficient time to enable the investigation to be completed, and a remand may be granted in writing. No remand shall be granted for more than fourteen days on each occasion.

${ }^{6}$ An Interview made with Bedasa Genemo, an investigative police officer in Batu police office, September 10, 2020

${ }^{7}$ Judicial power mean power of courts of law or other body of government granted with adjudicating power that is endowed with the authority to interpret and apply the law, adjudicate legal disputes, and otherwise administer justice.

${ }^{8}$ Article 79 (1) of FDRE Constitution Proclamation No. 1/1995

${ }^{9}$ An interview made with one of the judge's from Batu first instance court who's name wants to remain anonymous, September 11,2020

${ }^{10}$ As provided under Article 79 ( 2 \& 3) of the FDRE Constitution, Courts of any level shall be free from any interference of influence of any governmental body, government official or from any other source (i.e. Institutional independence), and judges shall exercise their functions in full independence and shall be directed solely by the law.
} 
The government led by Abiy Ahmed and his bureaucratic Amharan's continued re arresting opposition figures released on bail. ${ }^{1}$ The court ordered their release on bail ${ }^{2}$ but the government through its federal and Oromia police re arrest them or shift them from Finfinnee (Addis Ababa) police custody to neighboring towns than enforcing judicial orders. Abiy Ahmed government is completely eroded the country constitution and changed into dictator government. When courts of law ordered release of arrested opposition figures on bail but the government using its loyal law enforcement shifting and hiding arrested from federal policy custody to regional policy custody. This is a violation of sovereignty of regional and federal state recognized and incorporated in the country constitution. ${ }^{3}$ It is an erosion of federal type of state structure that country was for more than three decades. ${ }^{4}$ As mentioned above following the killing of Oromo music star Hachalu Hundesa thousands of Oromo's are suffering in different detention centers. They are beaten and humiliated by police and military force repeatedly. For instance, Melaku Dula who was detainee in Woliso police custody was charged before courts of law after two month of detention. Woliso high court ordered release on bail for Melaku Dula two times but police instead of releasing kept him in custody and continued humiliating and torturing him. After long time because Melaku was unable to stand against police torture and humiliation he was found dead. ${ }^{5}$ The law enforcement continued refusal to enforce courts order of release on bail of arrested and charged Oromo's exposed family to disintegration.

For instance, the case of Sisay Bekele who was arrested in Finfinnee as a part of crackdown unleashed by Abiy Ahmed government against the Oromo people following the killing of Hachalu Hundesa after brought to justice, the court ordered his release on bail and release of his blocked bank account. But the federal law enforcement refused to release Sisay Bekele and continued to keep him in prison. The law enforcement is not implementing the court order instead confirmed its loyalty to higher political officials. The government continued to keep blocking bank account of Sisay Bekele instead of respecting court order. Sisay Bekele wife Tejitu who was suffering from cancer for a long time passed away. She couldn't receive proper medical treatment because of unable to pay the amount of money offered as her husband bank account was blocked by the government. As Tejitu health got worse, her husband pleaded to enable his bank account for her medical treatment. He was remained unheard. He was denied to take part in her funeral and say goodbye to his wife. Up to this time his family and lawyer didn't know his where about after the court order his release on bail. ${ }^{6}$

The government after arresting prominent Oromo's like Jawar Mohammed, Bekele Gerba, Abdi Regassa, Lammi Begna and others from opposition political party immediately blocked their bank account. Families of Jawar Mohammed, Bekele Gerba and others unable to fulfill their basic needs for survival because of this bank account blockage. Abiy Ahmed government using the law enforcement including the defense force in a day light continued looting the property of Jawar Mohamed families in Adama. ${ }^{7}$

Abiy Ahmed government through attorney general's office and the law enforcement continued charging prominent politicians like Jawar Mohammed, Bekele Gerba, and twenty two others political prisoners with multi different crimes. Some of the crimes are inciting violence after the killing of Hachalu Hundesa, terrorism, telecom fraud and several other crimes. ${ }^{8}$ These are carefully orchestrated series of charges designed to eliminate Abiy Ahmed serious electoral adversaries from the political space.

For instance, in a recent press statement, Attorney general Gedion Timothewos told local and international journalists that Jawar Mohammed and twenty three (23) individual who are charged with terrorism and other criminal charges are "ultra-nationalist, militant, violent" individuals. According to Awol Kasim Alo this is a disturbing display of partiality and prejudice by attorney general and it constitutes an outrageous disregard for the defendant's fundamental right to presumption of innocence. ${ }^{9}$ The attorney general is the member of the

\footnotetext{
${ }^{1}$ Oromia police re arrest Misha Adem after he walks out of detention on bail, fail to disclose his where about, Addis Standard, 16 September, 2020. Retrieved from http://addisstandard.com, \& An interview made with Misha Adem lawyer Kedir Bullo from Oromia defense team, September 15, 2020

${ }^{2}$ Article 19 (6) of the FDRE Constitution provides that persons arrested have the right to be released on bail. In exception circumstances prescribed by law, the court may deny bail or demand adequate guarantee for the conditional release of the arrested person. Nature of offence, type of offence and degree of punishment cannot be ground for denial of right to bail. As long as the arrested person convince to appear before courts of law have the right to release on bail.

${ }^{3}$ As per Article $50(1 \& 8)$ of the FDRE Constitution, the federal democratic republic of Ethiopia comprises the federal government and the state members, and federal and state powers are defined by the FDRE Constitution. The state shall respect the powers of the federal government. The federal government shall likewise respect the powers of the states.

${ }^{4}$ As per Article 1 of the FDRE Constitution, This constitution establishes a federal and democratic state structure. Accordingly, the Ethiopian state shall be known as the federal democratic republic of Ethiopia (FDRE).

${ }^{5}$ Oromia Media Network (omn), Afaan Oromoo news, September 17, 2020. Retrieved from http://www.youtube.com

${ }^{6}$ Oromia Media Network (omn), Afaan Oromoo news, September 28, 2020. Retrieved from https://www.youtube.com, and interview made with Sisay Bekele lawyer from Oromo political prisoners defense team, September 29, 2020

${ }^{7}$ Oromia Media Network (omn), Afaan Oromoo news, September 28, 2020. Retrieved from https://www.youtube.com

${ }^{8}$ Simon Ateba, as dictatorship escalates, Ethiopia charges prominent opposition figure Jawar Mohammed with terrorism, September 19, 2020. Retrieved from https://todaynewsafrica.com

${ }^{9}$ Maleda Media, Press statement by Ethiopia Attorney General's, September 25, 2020. Retrieved from https://ne-np.facebook.com
} 
cabinet and the top law enforcement officer in the country. His view carries significant weight over law enforcement bodies, witnesses and perhaps members of the public, including judges, violating the defendant's right to get a fair and judicious hearing. Awol K. Alo argues that the intervention of attorney general in such prominent politician case is a serious breach of due process that the only outcome is to acquit the defendants. ${ }^{1}$ The attorney general's office established to serve with full professional and institutional independence but Gedion Timothewos statement is clear indication of his determination to use the attorney general's office to go after the political opponents of Abiy Ahmed. It is clear that these trials are not about the rule of law or justice. It is hard to expect justice from Abiy Ahmed government and an attorney general's that barely respects the decision of courts that are timidly trying their best.

\section{Concluding Remark}

International laws signed and ratified by the parliament recognize fundamental rights of arrested or accused persons. The grand constitution and other subordinate laws also recognize fundamental rights of arrested or accused persons. The Ethiopia criminal justice system reassembles to the due process model. The grand constitution guarantees the independence of the judiciary and the law enforcement as far as their powers and functions concerned. But always the governing body in Ethiopia had been involved in systematically creating more partial and dependent law enforcement and the judicial system. As a result of this for long time including the government led by Abiy Ahmed the judiciary and the law enforcement are serving the blood sucking politics than serving justice. Especially the judiciary and the law enforcement including attorney general used as political instrument to go after competent politicians against the governing body. But it is better for the law enforcement including the attorney general and the judiciary to serve as per the laws that highly protect fundamental rights and freedoms of arrested or accused. The law enforcement and the judiciary should at least to be subtle and project an aura of neutrality and independence.

\section{References}

1. Catherine Elliot and France Quinn, English legal system, (England: person education limited, $6^{\text {th }}$ ed., 2005)

2. Freda Adler, Gerhard O.W. Mueller, and William S. Laufer, A book on Criminal justice.

3. Herbert Packer, The limits of the criminal sanctions (Stanford, Calif.: Stanford University Press, 196 8).

4. James A. Inciardi, Criminal justice, (Fort Worth: Harcourt, Inc., Alabama ed., $7^{\text {th }}$ ed., 2002)

5. Marc Ancel, Social defense (Thorsten Sellin, transl.), (Little-ton, Colo.: Fred B. Rothman \& Co., 1987)

6. President's Commission on Law Enforcement and the Administration of justice, The Challenge of Crime in a Free Society (Washington, D.C.: U.S. Government printing office, 1967).

7. General Assembly of the United Nations (UN) adopted and proclaimed Universal Declaration of Human Rights (UDHR), December 10, 1948.

8. International Covenant on Civil and Political Rights (ICCPR), adopted and opened for signature, ratification and accession by General Assembly resolution 2200A (XXI) of December 16, 1966, entry into force March 23, 1976, in accordance with Article 49.

9. Maleda Media, Press statement by Ethiopia Attorney General's, September 25, 2020. Retrieved from https://ne-np.facebook.com

10. Oromia Media Network (omn), Afan Oromoo news, September 17, 2020. Retrieved from http://www.youtube.com

11. Oromia Media Network (omn), Afan Oromoo news, September 28, 2020. Retrieved from http://www.youtube.com

12. Oromia police re arrest Misha Adem after he walks out of detention on bail, fail to disclose his where about, Addis Standard, 16 September, 2020. Retrieved from http://addisstandard.com

13. Proclamation No. 1/1995, Constitution of the Federal Democratic Republic of Ethiopia, Federal Negarit Gazeta, $1^{\text {st }}$ year No. $1,21^{\text {st }}$ August 1995.

14. Proclamation No. 185/1961, Ethiopia Criminal Procedure, Imperial Ethiopia Government Negarit Gazeta, $21^{\text {st }}$ year No. 7, $2^{\text {nd }}$ November 1961.

15. Simon Ateba, as dictatorship escalates, Ethiopia charges prominent opposition figure Jawar Mohammed with terrorism, September 19, 2020. Retrieved from https://todaynewsafrica.com 